\title{
I. Observations on animal electricity, and particularly that called Spontaneous
}

\section{J.J. Hemmer}

To cite this article: J.J. Hemmer (1799) I. Observations on animal electricity, and particularly that called Spontaneous, Philosophical Magazine Series 1, 5:17, 1-7, DOI: $10.1080 / 14786449908677105$

To link to this article: http://dx.doi.org/10.1080/14786449908677105

Published online: 18 May 2009.

Submit your article to this journal $[\pi$

Џ Article views: 2

Q View related articles $\sqsubset$ 
THE

\title{
PHILOSOPHICAL MAGAZINE.
}

\author{
OCTOBER 1799 .
}

I. Obfervations on Animal Eleatricity, and particularly that called Spontaneous. By J. J. He M MER *.

$\mathrm{U}$

NDER Animal Electricity I underftand that kind obferved in animals, from whatever caufe it may arife. When this electricity is excited in animals, neither by the peculiar movement of their own bodies, nor by friction, or the application of any other body, it is called Spontaneous Animal Electricity. We are taught by many inftances, both ancient and modern, that men, as well as other animals, have exhibited evident figns of electricity; although the ancients, who mention thefe inftances, did not know to what the phenomenon was to be afcribed. It may not be improper, therefore, to quote here fome of the moft remarkable of them.

1. We are told by Virgil, that the hair of Afcanius emitted a harmlefs kind of flame $\uparrow$.

Ecce levis fummo de vertice vifus Iuli

Fundere lumen apex, tactuque innoxia molli

Lambere flamma comas, et circum tempora pafci.

Nos pavidi trepidare metu, crinemque flagrantem

Excutere, et fanctos reftinguere fontibus ignes.

* From the Tranjadions of the Electoral Academy of Sciences at Manbeim, Vol. VI.

\$ Ineid, Lib. II. v. 582 .

Vot. V. 
II. We are informed by Dionyfius and other writers, that fire ftreamed forth from the hair of Servius Tullius, the Roman king, during lleep, when he was about feven years of age *.

III. Pliny alfo fpeaks of light often mining around the heads of men:-Hominum quoque capita veppertinis boris Jelle magno prefagio circumfulgent $\uparrow$.

IV. We are told of a Carmelite monk, who was always attended with this phenomenon, that, as oft as he ftroked his hair backwards, it emitted fparks $\ddagger$.

V. A woman at Caumont exhibited a phenomenon of the like kind, as her hair, when combed in the dark, always emitted fire $\S$.

VI. Father J. Faber fpeaks of a young woman from whofe head fparks of fire always fell when the combed her hair $\|$.

VII. Francifcus Guidus produced bright flames from his body when he rubbed his arm with his hand as he lay in bed $\uparrow$.

VIII. Ezekiel de Caftro**, a phyfician of Verona, relates the following circumftance refpecting Caffandra Buri, a lady of the fame place:-As often as the touched her body, even in a llight manner, with a linen cloth, it emitted fparks in great abundance, which could be perceived by every perfon ftanding near her, and which were attended with a confiderable noife. Her maids were often deceived by this phenomenon, and believed that they had, through careleffnefs, dropped fome coals between the fheets, as the always caufed her bed to be warmed in winter, at which time the fparks were moft abundant and ftrongeft.

IX. Anthony Cianfi, a bookfeller at Pifa, when he pulled off a narrow thirt, and a piece af cloth which be wore on his breaft, emitted fparks from his back and arms, with a crack-

* Antiq. Rom. Lib. IV.

+ Hift. Nat. Lib. II. cap. xxxvii.

\$ Cardanus, Lib. VIII. de rerum variet. cap. xliii.

$\S$ Scaliger. Exer. 174 .

II In his Palladium Chymicum.

TI Bartholinus de luce animalium, Lugd. Bat. 1647 , p. I2 1.

** In lis book De igne lambente. 
ling noife, to the great terror of his whole family. Fortunius Licetus was a witnefs of this phenomenon *.

X. " Among us," fays Gefner, "where heated chambers are ufual, it often happens that many perfons, when they have warmed themfelves at a ftove, and then pull off their thirt in a cold bed-chamber, or move or thake it after it is pulled off, obferve crackling flames to burft from it $\uparrow . "$

XI. Bartholinus fays, that a rope-dancer at Turin, according to the teftimony of a refpectable man, Caffiano a Puteo, emitted a like phenomenon of light from his body $t$.

XII. The fame author fays, that fparks proceed from the fkins of cats, and particularly from the back; which can be clearly perceived by ftroking the hair backwards even with the leaft preffure, and efpecially after they have been warmed at the fire $\S$.

XIII. Scaliger fpeaks of a white Calabrian horfe, which, when combed in the dark, emitted fparks of fire $\|$.

XIV. Ezekiel de Caftro fays $q$, of another horfe of the fame kind, that real fparks were obferved when his neck was ftroked upwards with the hand or a currycomb.

XV. Simpfon treats of the light emitted by the bodies of animals when rubbed; and quotes inftances of fuch phenomena on combing the hair of a woman, currying a horfe, and ftroking a cat with the hand ${ }^{*} *$.

XVI. The following circumftance refpecting himfelf was told by Vaudania to the celebrated Beccaria :- " For ten or twelve days paft, fince the cold fet in, I wear, between two fhirts, a piece of beaver's fkin. Always when I pull off my upper hirt at night, I obferve that it adheres, in fome degree, to the piece of fkin; and when I draw my thirt from it, I fee fparks which have a ftriking refemblance to thofe of electricity. Scarcely do I begin to pull off the piece of fkin

* Licetus de cauffis monftrorum, Lib, II. cap. xxviii.

+ Lib. de lunariis.

$\ddagger$ De luce animali, p. 123 .

$\$$ Ibid. p. 189 .

II Exercitat. 174.

Il Liber de igne lamb.

* Diff. Phyf. de fermentatione, 1675 . 
when I find that it adheres, and with ftill greater force, to the under-thirt. On taking it out I obferve, when I hold it in the right hand, that the frill of my thirt moves up from my body towards it. If I remove the piece of fkin to $a$ greater diftance, and draw it from the frill, the latter moves again towards my body. If I bring the piece of lkith nearer, the thirt moves again towards it. This of cillation of $m$ thirt between my body and the piece of fkin continues al, ternately, till it is gradually leffened, and at length ceafes:"

XVII. About twelve years ago the following circimftanct was communicated to bur Academy; in writing, from Berdigheim :-On the ith of February a young woman havint put on an aired hift, which was exceedingly narrow and fat very clofe to her body; heard, on laying hold of it, a crackling noife like what oftimes proceeds from the flame of a candle, and obferved fparks to iffue from all thofe places which the touched with her hands. Being aftonimed at this phenomenon, the called to another girl, who flept in the next apartment, to come to her affiftance, as her fhift, which the in the mean time pulled off, was on fire. They both now thook the fhift in order to extinguirf the fparks; but the more they moved it, the effects were ftronger: on examining the fhift, however, no traces of fire could be difcovered. The firft maid then put on another thift, which the took from her box; but as foon as fhe touched it, the fame crackling noife and appearance of fparks took place. She then put on her dirty fmock, which the had before pulled off, and returned to bed, on which the ptienomenon difappeared, Some perfons to whom the circumftance was afterwards related, were defirou's to know whether the fame phenomerna would again appear if the maid put on shother clean thift. She did fo the following night; and as often as the fmock was touched by her or any other perfon, a crackling noife was heard, and fparks were emitted every time the finger was brought near it. The fpectators now defired her to put on another clean fmock, which belonged to another maid: on approaching the hand a like noife was heard, and the appearance of fire was obferved; but no fparks iffued from her body, even though touched, when the had the thift on. 


\section{Obfervations on Animal EleEtricity.}

An experiment was then made to try whether the fame phenomena would occur if another woman put on the girl's fhift; but nothing of the kind was obferved either by the perfon who had put it on, or by thofe who touched it; but the phenomena were repeated when it touched the maid on whom they had been firft obferved. Every time after this period that the fame perfon put on a clean fmock, the fame effects were produced; but they difappeared after the thift had been worn fome days. On the Ift of February the whole phenomenon ceafed, and after that time never returned.

XVIII. M. Flad junior, member of our Society, having been in a confumptive ftate about eight years ago, obferved, for a long time, as often as he pulled off or drew on his Itockings, that fparks proceeded from his feet in abundance. Having afterwards recovered his ftrength in fome meafure, the fparks difappeared; but they returned when his ftrength again began to decreafe, and continued till his diforder put an end to his exiftence.

XIX. As often as M. Hertel, chaplain to the Elector, draws his hand over his breaft, which is covered with hair, abundance of fparks are feen in the dark.

XX. I was told by Count von Kagenek, that it often happened to him, that when he drew a filk handkerchief between his fingers, while ftanding near a ftove, long luminous fripes were here and there obferved.

XXI. I was told alfo by a lady named Von Fraife, that very often, when the rubbed her hands or arms even weakly with a linen cloth, lying in bed, abundance of fparks iffued from them.

XXII. M. Von Schlemmer, of Deux-Ponts, relates of a lady named Von Koch, that the often obferves, when the gets up early, that a ribbon, with which fhe binds up her hair during the night, adkeres to her fingers when the pulls it off, and moves with velocity towards other neighbouring bodies. Having, by my defire, applied to the ribbon a piece of fealing wax, which had been rabbed, it was always repelled by it.

XXIII. I am acquainted with another lady, whofe hair, when 
when combed in the dark, always has a luminous appearance, as I have fometimes obferved myfelf.

XXIV. I have a white horfe, from the body of which, particularly in the winter-time, the comb brings forth abundance of fparks. I have likewife a white $\mathrm{dog}$, from the back of which, when I draw my hand over it, in a warm room, from the tail to the head, fparks iffue with a fnapping noife, and which feem fo troublefome to the animal, that he endeavours to run away. I have fometimes charged a jar with them.

XXV. I have often produced the fame phenomenon on an aft-grey, ftrong, lively cat.

XXVI. We are acquainted with three kinds of 6ih which, when touched, give a Mrock almoft like that occafioned by a charged jar, viz. the cramp-ray, Raia torpedo L.; the electrical eel, Gymnotus electricus L.; and the Silurus electricus L. The more modern philofophers have convinced themfelves, by repeated experiments, that the effects of the fhock given by thefe animals are of an electric nature, though to me it appears probable that they depend, in part, on another caufe.

The animal electricity which $I$ have announced in thefe numerous inftances is of the coarfer kind, and may be eafily obferved by every one; but there is another kind, of a more delicate nature, which does not fpontaneoully manifeft itfelf, but muft be concentrated and called forth by art. This finer electricity $I$ find firft mentioned in a letter of M. de Sauflure to the editor of the Journal de Pbyfque at Paris. The experiments. which this celebrated philofopher made, partly on himfelf and partly on others, by means of Volta's electrometer and condenfer, are given there only in extracts; but the confequences he deduces from them are as follows :

In order to produce this electricity, bodily motion is neceffary. The electricity thence produced arifes from the friction of the body againft the clothes; for as often as he made the experiment naked, he found no electricity. In order that electricity may be produced by the friction of the body againft the clothes, the latter muft poffefs the natural warmth of the body; for when he had on clothes that were cold, he could never perceive the leaft trace of electricity: no electricity 
tricity appears alfo when the body is in a ftate of perfpiration. There are perfons who, in this manner, never emit electricity. The electricity which thews itfelf in the human body is pofitive, and fometimes negative. The caufe of this variation he was not able to difcover.

[To be concluded in next Number.]

II. On the Method of Diftilling as practifed by tbe Natives at Cbatra in Ramgur, and otber Parts of Inidia. By Archibald KeIr, Efq.*

$\mathrm{T}$

HE body of the ftill they ufe is a common, large, unglazed, earthen water-jar, nearly globular, of about twentyfive inches diameter at the wideft part of it, and twenty-two inches deep to the neck, which neck rifes two inches more, and is eleven inches wide in the opening. Such, at leaft, was the fize of the one I meafured; which they filled about a half with fomented Mâhwah flowers, that fwam in the liquor to be diftilled.

The jar they placed in a furnace, not the moft artificial, though feemingly not ill adapted to give a great heat with but very little fuel. This they made by digging a round hole in the ground, about twenty inches wide, and full three feet deep; cutting an opening in the front, Aloping down to the bottom, on the fides perpendicular, of about nine inches wide and fifteen long, reckoning from the circle where the jar was to come, to ferve to throw in the wood at, and for a paffage to the air. On the fide too they cut another fmall opening of about four inches by three; the jar, when placed, forming one fide of it, to ferve as a chimney for the fmoke to go out at. The bottom of the earth was rounded up like a cup. Having then placed the jar in this, as far as it would go down, they covered it above, all round, with clay, except at the two openings, till within about a fifth of its height; when their furnace was completed.

In this way I reckon there was a full third of the furface

* From the Afjatic Reffarckes. 